\title{
Article
}

\section{London or New York: where and when does the gold price originate?}

O'Connor, Fergal A., Lucey, Brian M. and Larkin, Charles

Available at http://clok.uclan.ac.uk/6563/

O'Connor, Fergal A. ORCID: 0000-0002-2877-8098, Lucey, Brian M. and Larkin, Charles (2013) London or New York: where and when does the gold price originate? Applied Economics Letters, 20 (8). pp. 813-817. ISSN 1350-4851

It is advisable to refer to the publisher's version if you intend to cite from the work. http://dx.doi.org/10.1080/13504851.2012.748175

For more information about UCLan's research in this area go to http://www.uclan.ac.uk/researchgroups/ and search for <name of research Group>.

For information about Research generally at UCLan please go to http://www.uclan.ac.uk/research/

All outputs in CLoK are protected by Intellectual Property Rights law, including Copyright law. Copyright, IPR and Moral Rights for the works on this site are retained by the individual authors and/or other copyright owners. Terms and conditions for use of this material are defined in the policies page.

\section{CLoK}

Central Lancashire online Knowledge www.clok.uclan.ac.uk

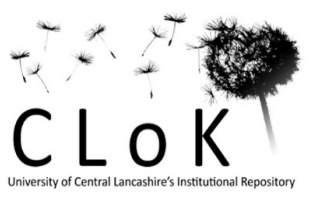


London or New York: where and when does the gold price originate?

Brian M Lucey: (corresponding author): Business School and Institute for International Integration Studies, Trinity College Dublin, Dublin 2, Ireland. Glasgow School for Business, Glasgow Caledonian University, Scotland, UK blucey@tcd.ie

Charles Larkin: Business School and Institute for International Integration Studies, Trinity College Dublin, Dublin 2, Ireland, and Cardiff School of Management ,Cardiff Metropolitan University, Llandaff Campus, Western Avenue, Cardiff , CF5 2YB , UK. Charles.larkin@gmail.com

Fergal A. O'Connor: Business School and Institute for International Integration Studies, Trinity College Dublin, Dublin 2, Ireland. Fergal.a.oconnor@gmail.com

Abstract

We investigate the information shares of the two main centers of gold trading, over a 25 year period, using non overlapping 4 month windows. We find that neither London nor New York are dominant in terms of price information share, that the dominant market switches from time to time and that these switches do not appear to be very clearly linkable to macro-economic or political events.

Keywords: Gold, information share, COMEX, LBMA

JEL Code C01, F49, G12, G15, 
London or New York : In which does the gold price originate and when?

\section{Introduction}

The world market for gold is characterised by worldwide trading. Gold is traded OTC worldwide and financial gold products (ETF's, Futures and other derivatives) on a wide variety of organized exchanges and platforms. The world market for gold in 2011 was of the order of 4,000 tonnes, equivalent to over $\$ 200 \mathrm{~b}$. And yet, the market remains in many ways bipolar both in terms of location and product. A good description of the emergence of the world gold markets is to be found in O'Callaghan (1991). Much gold demand is for jewellery, or industrial purposes, but investment represents approximately $36 \%$ of the estimated 2011 demand, with $90 \%$ of this being for physical bullion (World Gold Council (2012)).

Table 1 shows the dominance of London as a trading center for gold with $86 \%$ by volume in 2011 terms occurring there. Of this, approximately $90 \%$ of the trade is physical, OTC spot transactions. Recent research (Murray (2011)) has made clear for the first time the volume and nature of this OTC market. The only other market of comparable size is the New York market, dominated by COMEX Futures.

Nonetheless, while smaller, it is reasonable to wonder if given the more transparent nature of futures and options markets whether these might not in fact be a more efficient and informative market in terms of price setting. The consensus in literature for stock and currency futures and options is that futures markets lead spot markets in terms of information and price discovery (see Bohl, Salm, and Schuppli (2011), Rosenberg and Traub (2009)). Despite its importance, with the gold market representing approximately the same gross size as the US-Australian and US - Canadian dollar foreign exchange markets (based on 2010 data in Bank for International Settlements (2011)) we find surprisingly little research has been undertaken on this 
area in the gold market. Xu and Fung (2005) and Lin, Chiang, and Chen (2008) use GARCH models to examine the COMEX-TOCOM linkages, while Fuangkasem, Chunhachinda, and Nathaphan (2012) look at the COMEX-MIX (india)- TOCOM markets. The general consensus is that COMEX dominates. All of these papers concentrate on futures markets, which misses the overwhelming dominance of the London market.

Table 1: Gold Spot, Futures and Options Trading volumes 2011

\begin{tabular}{|l|l|l|}
\cline { 2 - 3 } \multicolumn{1}{c|}{} & 2011, '000 ounces & \% of Total Volume \\
\hline UK & $43,775,704$ & $86.75 \%$ \\
America & $4,991,604$ & $9.89 \%$ \\
China & 697,002 & $1.38 \%$ \\
India & 494,547 & $0.98 \%$ \\
Japan & 488,502 & $0.97 \%$ \\
Dubai & 12,507 & $0.02 \%$ \\
\hline Total Volume & $50,459,865$ & \multicolumn{1}{|c}{} \\
\cline { 1 - 3 } & &
\end{tabular}

Source: UK data annualized from Murray (2011), all others from GFMS ltd (2012)

\section{Information Flows}

Two popular approaches have been deployed to investigate extent to which one market informs the price in another market. They use two quite distinct approaches, and the Hasbrouck (1995) methodology gives us upper and lower bounds for these shares while the Gonzalo and Granger (1995) model provides a unique level. Both rely on the concept that the prices of the two assets being investigated share a common trend or a steady state to which they return, that they are cointegrated.

Because the relationship between the two gold prices is cointegrated we can form an error correction model with $G_{1, t}$ and $G_{2, t}$ denoting the two gold prices as in (1) below.

$$
\Delta G_{t}=\propto \quad \beta^{\prime} G_{t-1}+\sum_{i=1}^{q} A_{i} \Delta G_{t-i}+e_{t}
$$


Where $G_{\mathrm{t}}=\left(G_{1, t}, G_{2, t} .\right)^{\prime}$ is the gold price vector, $\propto=\left(\propto_{1}, \propto_{2}\right)^{\prime}$ is the vector of error correction coefficients, $\beta$ is the cointegrating coefficient vector and $\operatorname{ET}=\left(\mathrm{e}_{1, \mathrm{t}}, \mathrm{e}_{1, \mathrm{t}}\right)$ is the normally distributed error term. As Zhang and Wei (2010) point out if there is no autocorrelation with respect to these error terms then the covariance matrix can be written as in (2) below.

$$
\Omega=\left(\begin{array}{cc}
\sigma_{1}^{2} & \rho \sigma_{1} \sigma_{2} \\
\rho \sigma_{1} \sigma_{2} & \sigma_{2}^{2}
\end{array}\right.
$$

Where $\sigma_{1}^{2}$ and $\sigma_{2}^{2}$ are the variance of $\mathrm{e}_{1, \mathrm{t}}$ and $\mathrm{e}_{2, \mathrm{t}}$ and $\rho$ is their correlation coefficient.

Following Stock and Watson (1988) and Baillie et al. (2002) the vector of gold prices $\mathrm{P}_{\mathrm{t}}$. between a common factor $\left(\mathrm{f}_{\mathrm{t} .}\right)$ representing the common trend for the two prices and transient effects $\left(a_{t}\right)$ such as inventory adjustments which have a short term influence on price.

$$
\mathrm{P}_{\mathrm{t}}=\mathrm{f}_{\mathrm{t}}+\mu_{\mathrm{t}}
$$

$\mathrm{f}_{\mathrm{t}}$ is defined by Gonzalo and Granger (1995) as a linear combination of the two prices, $\mathrm{f}_{\mathrm{t}}$ $=\gamma_{1} G_{1, t}+\gamma_{2} G_{2, t}$, where $\gamma_{1}$ and $\gamma_{2}$ are the coefficients of the vector of the common factor, which by definition sum to1. Gonzalo and Granger (1995) proved that this vector is orthogonal to the $\propto$ vector of the ECM thus $\propto_{1} \gamma_{1}+\propto_{2} \gamma_{2}=0$. Therefore $\gamma_{1}$ and $\gamma_{2}$ can be interpreted as being the contributions of the two markets to price discovery. 
If there is no significant correlation between the residual terms of the cointergating regressions we can specify the IS model as in (4):

$$
I S_{i}=\frac{\gamma_{i}^{2} \sigma_{i}^{2}}{\gamma_{1}^{2} \sigma_{1}^{2}+\gamma_{2}^{2} \sigma_{2}^{2}}, \mathrm{I}=1,2
$$

Where IS $S_{\mathrm{i}}$ is the information share of market I and $\sigma_{j}^{2}$ is the variance of market $\mathrm{i}$. If there is correlation between the two error terms the covariance of the error terms of the vector error correction model is transformed using a Cholesky factorization $\Omega=$ MM' so that:

$$
M=\left(\begin{array}{cc}
m_{11} & 0 \\
m_{21} & m_{22}
\end{array}\right)=\left(\begin{array}{cc}
\sigma_{1} & 0 \\
\rho \sigma_{2} & \sigma_{2}\left(1-\rho^{2}\right)^{\frac{1}{2}}
\end{array}\right)
$$

From this the IS becomes:

$$
\begin{aligned}
& I S_{1}=\frac{\left(\gamma_{1} m_{11}+\gamma_{2} m_{21}\right)^{2}}{\left(\gamma_{1} m_{11}+\gamma_{2} m_{21}\right)^{2}+\left(\gamma_{2} m_{22}\right)^{2}} \\
& I S_{2}=\frac{\left(\gamma_{2} m_{22}\right)^{2}}{\left(\gamma_{1} m_{11}+\gamma_{2} m_{21}\right)^{2}+\left(\gamma_{2} m_{22}\right)^{2}}
\end{aligned}
$$

From these it can be seen that IS ${ }_{1}+I_{2}=1$. This factorization has the effect of giving the first market a greater share of the information. Therefore when the London market is the first this gives up an upper limit and when it is second a lower limit of its information share. Following Zhang and Wei (2010) and Baillie et al. (2002)the average of these upper and lower limits is given as the estimate of a markets information share. 
We estimated these statistics shares using the statistical package $R$, the program infoshare.R.

\section{Data}

We use COMEX one-month future closing price and the London Bullion Market AM Fix to represent the future and spot markets respectively.

We use prices from January 1986 through the end of July 2012, giving 6915 observations. There is a $99.98 \%$ correlation between the price levels, and a single cointegrating rank (test statistics available on request) exists between these assets. We subdivided the data into non-overlapping windows of 100 days, approximating 4 months trading. The work of Tully and Lucey (2007) suggests that shocks to the gold price decay relatively slowly, but would be well dissipated within that period .

\section{Results}

The information shares are graphed in Figure 1 and Figure 2. Following Baillie et al. (2002) we show the midpoint of the estimated Hasbrouck Information Shares.

We note a number of issues. First, there is no clear evidence of any one market being dominant. The average for London share of the price discovery is $55 \%$ using the GG approach and using the (midpoint) Hasbrouck estimates 45\%. We can safely therefore conclude that there is a bipolar world with London AM fix prices informing the NY futures close which informs the following AM fix. The world gold price is not made in any single market.

Second, price discovery is unstable. We see times when the price discovery is shared, other times when it is concentrated in one or other market. 
Third, analysis of the data does not show obvious linkages to particular economic or routine political events causing switches in price discovery between the London and New York markets. The transitions of prime ministers, presidents, Fed chairmen and Bank of England governors do not have any apparent impact on the switching between locations. Equally, changes in Fed Funds rate and the Bank Rate of the Bank of England have no clear impact on discovery.

Fourth, despite this some evidence suggests particular causal relationships. Thus, there is a shift to the London market that coincides with the slow collapse of the Eastern Bloc beginning with the protests in the summer of 1989 , which also coincided with the peak of the Japanese asset price bubble.

The interesting aspect of the 1990 switch from New York to London is that it happens around the time of the NBER US business cycle change from expansion to contraction. London contributes the largest share to price discovery while there occurs a series of important European political events related to the re-unification of Germany, the fall of Thatcher and the move to the US business cycle towards expansion. Interestingly, Gulf War I does not seem to have any impact on the switching between London and New York, despite the traditional assumption that wars and other destabilizing political events have profound impacts on the gold markets (Preiss (2002).)

The switch back to London from New York happens again at the time of the 1992 Exchange Rate Mechanism crisis and the clear pressures being brought to bear on Sterling. . Outside of the ERM Crisis and the wave of devaluations across European monetary events, prior to the Eurozone Crisis, European events do not seem to have any impact on the switching of markets.

Global economic crises may have an impact on switching depending on their location and implied political implications. The switch from the London Markets to the New York Markets occurs at the start of the Ruble Crisis and the bailout of LTCM as opposed to the start of the Asian Crisis. 
There is some active switching between markets between the Dot-Com Bubble peak in March 2000 and the beginning of the Dot-Com Bust recession in March 2001. Following the 9/11 attacks the New York market becomes the dominant contributor. The New York market remains so throughout the downturn and into the expansion phase in the US economy before switching to London

New York becomes dominant at the start of the global financial crisis just following the open concerns about US Treasury bonds. It remains dominant until August 2008. Interestingly London is dominant throughout the Lehman's event, with the market only switching to New York as the NBER contraction period comes to a close and the US begins its anemic expansion. The final switch to New York in April 2011 does not seem to have been triggered by any geopolitical or economic event and must therefore be driven by the gold market itself.

The interesting aspects of the moves between New York and London are that they appear therefore except in examples of globally important phenomenon, to be sui generis. The unanswered question is to try to understand, possibly via a behavioral or ethnographic study what are the key decision triggers for gold market actors in switching the locus of "price maker" from one market to another. 


\section{References}

Baillie, Richard T, G Geoffrey Booth, Yiuman Tse, and Tatyana Zabotina, 2002, Price discovery and common factor models, Journal of Financial Markets 5, 309-321.

Bank for International Settlements, 2011, Triennial central bank survey report on global foreign exchange market activity in 2010.

Bohl, M T, C A Salm, and M Schuppli, 2011, Price discovery and investor structure in stock index futures, Journal of Futures Markets 31, 282-306.

Fuangkasem, Rapeesorn, Pornchai Chunhachinda, and Sarayut Nathaphan, 2012, Information transmission among world major gold futures markets: evidence from high frequency synchronous trading data, .

GFMS ltd, 2012, Gold survey 2012.

Gonzalo, J, and C W J Granger, 1995, Estimation of common long-memory components in cointegrated systems, Journal of Business and Economic Statistics 13, 27-35.

Hasbrouck, J, 1995, One security, many markets: determining the contributions to price discovery, Journal of Finance 50, 1175-1199.

Lin, Hui-Na, Shu-Mei Chiang, and Kun-Hong Chen, 2008, The dynamic relationships between gold futures markets: evidence from comex and tocom, Applied Financial Economics Letters 4, 19-24.

Murray, Stuart, 2011, Loco london liquidity survey, Alchemist 63, 9-10.

O'Callaghan, Gary, 1991, The structure and operation of the world gold market, (IMF, New York).

Preiss, Michael R, 2002, In gold we trust, Far Eastern Economic Review 165, 30.

Rosenberg, J.V.a, and L.G.b Traub, 2009, Price discovery in the foreign currency futures and spot market, Journal of Derivatives 17, 7-25.

Stock, J H, and M W Watson, 1988, Testing for common trends, Journal of the American Statistical Association.

Tully, E, and B M Lucey, 2007, A power garch examination of the gold market, Research in International Business and Finance 21, 316-325.

World Gold Council, 2012, Gold demand trends second quarter 2012. 
Xu, Xiaoqing Eleanor, and Hung-Gay Fung, 2005, Cross-market linkages between u s and japanese precious metals futures trading, Journal of International Financial Markets, Institutions and Money 15, 107-124.

Zhang, Yue-Jun, and Yi-Ming Wei, 2010, The crude oil market and the gold market: evidence for cointegration, causality and price discovery, Resources Policy 35, 168-177. 
Figure 1 : Hasbrouck Information Share



Figure 2 : Gonzalo Granger Information Share

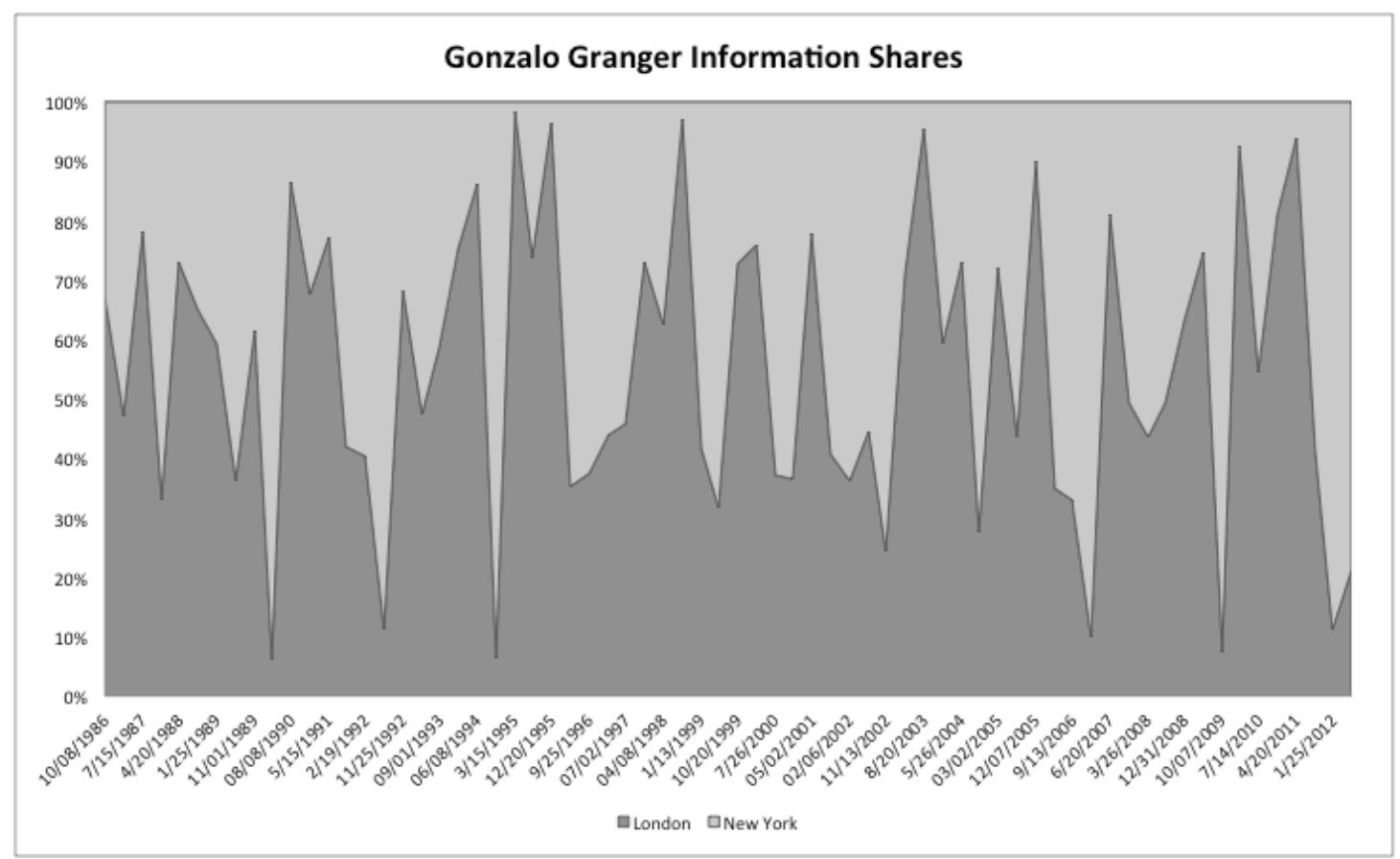

